\title{
Differential tolerance of crotalaria species to herbicides
}

\author{
Marcelo Rafael Malardo', Patrícia Andrea Monquero'*, \\ Paulo Vinicius da Silva², Andreia Cristina Silva Hirata ${ }^{3}$ \\ ederal University of São Carlos, Araras, SP, Braz \\ ${ }^{2}$ University of São Paulo, Piracicaba, SP, Brazil \\ ${ }^{3}$ Agência Paulista de Tecnologia dos Agronegócios, Presidente Prudente, SP, Brazil \\ *Corresponding author, e-mail: pamonque@cca.ufscar.br
}

\begin{abstract}
Annual crops and crotalaria intercropping has been used to control nematodes. The evaluation of the susceptibility of crotalaria species to herbicides is an important step to make this technology viable. The aim of this experiment was to determine the tolerance of Crotalaria juncea, C. ochroleuca, C. spectabilis and C. breviflora to pre and post-emergence herbicides. Post-emergence (bentazon, ametryn, amicarbazone, 2,4-D amine and mesotrione) and preemergence herbicides (atrazine + mesotrione, atrazine + simazine, atrazine, isoxaflutole, pendimenthalin, s-metolachlor and trifluralin) were evaluated in doses of 0.5D; 0.75D; 1D and 1,25D; in which D was the commercial dose of each product. The results demonstrated that the species of crotalaria differ on the susceptibility to pre and post emergence herbicides. Among the post-emergence herbicides, bentazon showed higher selectivity. However, reduced doses of some post-emergence herbicides can make the intercropping with some species of crotalaria viable. The most selective pre-emergence herbicides were pendimenthalin, s-metolachlor and trifluralin. In general, C. spectabilis was the most susceptible to the evaluated herbicides.
\end{abstract}

Keywords: green manure, intercropping, selectivity

\section{Introduction}

Root-knot nematodes, Meloidogyne spp., are considered one of the most important phytoparasite nematodes. They are highly pathogenic to different species of economic importance and are widely disseminated in crop areas (Carneiro, 2007).

In integrated management of nematodes, combined strategies such as exclusion measures, use of antagonistic plants, chemical control, green manuring, resistant cultivars, crop rotation, set-aside system and biological control should be used (Ritzinger \& Fancelli, 2006). The chemical control has been the most used nematode control method (Araujo ef al., 2012). However, the indiscriminate use of nematicides can burden the production, endangers rural operators' health and also exert strong selection pressure on the organisms in the soil. In this context, different species of crotalaria can be used in crop rotation systems or intercropping aiming at the control of $M$. incognita and M. javanica (Ritzinger \& Fancelli, 2006; Gardiano et al., 2010; Asmus \& Richettl, 2010; Araujo et al., 2012).

However, the herbicides used in weed management may affect the establishment and development of crotalaria plants, which would impair its use as a nematicide. Inove et al. (2012) found differences in the susceptibility 
to herbicides among crotalaria species and verified that sequential application of glyphosate caused phytotoxicity in C. spectabilis and C. ochroleuca. Associations of glyphosate with 2,4-D, flumioxazine and metsulfuron-methyl were phytotoxic to C. spectabilis. Associations of glyphosate with carfentrazone-ethyl and glyphosate with saflufenacil caused the death of C. ochroleuca. Flumioxazin was the only herbicide that did not kill plants of both species.

Stem diameter, number of seeds per pod and weight of 1,000 seeds of $C$. juncea were not affected by the application of glyphosate in subdoses $\left(0,30,60,90\right.$ and $\left.120 \mathrm{~g} \mathrm{ha}^{-1}\right)$. However, there was a direct effect in crop yield (Kappes et al., 2012). Adult plants of C. juncea were susceptible to the association of glyphosate with paraquat (Torres et al., 2008). In another study, glyphosate in isolated application or in association with 2,4-D or metsulfuron-methyl, permitted regrowth when applied in adult plants of C. juncea (Espanhol et al., 2011).

C. juncea showed inhibited growth up to

Table 1. Result of chemical and physical soil analysis.
13 months after tebuthiuron application, which demonstrates its high susceptibility and indicates that the residual effect of this herbicide can restrict the sugarcane crop reform with the use of crotalaria (Pires et al., 2008).

Despite the prominence of crotalaria as green manure in recent years, studies are needed to evaluate the selectivity of herbicides. Therefore, the aim of this study was to determine the tolerance of Crotalaria breviflora, C. juncea, C. ochroleuca and C. spectabilis to pre and post-emergence herbicides.

\section{Materials and methods}

Experiments involving herbicides applied in pre-emergence and post-emergence of crotalaria species were installed in a greenhouse in a completely randomized design with four replicates.

In all the experiments, the experimental unit was composed of $1 \mathrm{~L}$ pot, filled with clayey soil, from the arable layer of a dystrophic Red Latosol, (EMBRAPA, 1999), whose chemical and physical analysis can be visualized in Table 1.

\begin{tabular}{|c|c|c|c|c|c|c|c|c|c|c|c|c|c|}
\hline \multicolumn{14}{|c|}{ Dystrophic Red Latossol } \\
\hline $\mathrm{P}$ & $O . M$ & $\mathrm{pH}$ & K & $\mathrm{Ca}$ & $\mathrm{Mg}$ & $\mathrm{H}+\mathrm{Al}$ & $\mathrm{Al}$ & SB & CEC & $\mathrm{V}$ & Clay & Sand & Silt \\
\hline $\mathrm{mg} \mathrm{dm}^{-3}$ & $\mathrm{~g} \mathrm{dm}^{-3}$ & $\mathrm{CaCl}_{2}$ & \multicolumn{7}{|c|}{$\mathrm{mmol} \mathrm{dm}^{-3}$} & $\%$ & & $\mathrm{~g} \mathrm{~kg}^{-1}$ & \\
\hline 15 & 24 & 5.1 & 2.5 & 28 & 12 & 40 & 0.4 & 42.5 & 82.5 & 52 & 660 & 150 & 190 \\
\hline
\end{tabular}

All the experiments were carried out in a $5 \times 4$ factorial scheme, with five doses of each herbicide $(0 D, 0.5 \mathrm{D}, 0.75 \mathrm{D}, 1 \mathrm{D}$ and 1.25; $\mathrm{D}$ as the commercial dose) and four species of crotalaria (Crotalaria breviflora, C. juncea, C. ochroleuca and C. spectabilis). For the experiment with 7 herbicides applied in pre-emergence, atrazine $\left(D=2500 \mathrm{~g} \mathrm{ha}^{-1}\right)$, atrazine + mesotrione $(D=1200$ $\left.+120 \mathrm{~g} \mathrm{ha}^{-1}\right)$, atrazine + simazine ( $\mathrm{D}=250+250 \mathrm{~g}$ $\mathrm{ha}^{-1}$ ), isoxaflutole ( $\mathrm{D}=60 \mathrm{~g} \mathrm{ha}^{-1}$ ), pendimenthalin $\left(D=1500 \mathrm{~g} \mathrm{ha}^{-1}\right)$, trifluralin ( $\left.\mathrm{D}=2400 \mathrm{~g} \mathrm{ha}^{-1}\right) \mathrm{e}$ s-metolachlor ( $D=1400 \mathrm{~g} \mathrm{ha}^{-1}$ ) were evaluted. In the experiment with 6 post-emergence herbicides, bentazon ( $D=720 \mathrm{~g} \mathrm{ha}^{-1}$ ), ametryn ( $\mathrm{D}=2000 \mathrm{~g} \mathrm{ha}^{-1}$ ), amicarbazone ( $\mathrm{D}=280 \mathrm{~g} \mathrm{ha}^{-1}$ ), mesotrione ( $\left.D=144 \mathrm{~g} \mathrm{ha}^{-1}\right)$ and 2,4-D amine ( $D=$ $1000 \mathrm{~g} \mathrm{ha}^{-1}$ ) were evaluated.

The seeds of $\mathrm{C}$. breviflora, $\mathrm{C}$. juncea, C. ochroleuca and C. spectabilis were purchased from a company specialized in the production of

green manure seeds and sowing was performed by sowing five seeds per pot. During the experimental period, the pots were submitted to five daily irrigations, with approximately 0.50 $\mathrm{mm}$ each to maintain soil moisture, ensuring the germination and plants emergence.

The application of pre-emergence herbicides was carried out one day after crotalaria sowing. It was applied with a $\mathrm{CO}_{2}$ pressurized costal spray with a pressure of $30 \mathrm{lbs}$ pol- $^{-2}$, equipped with bar with two fanshaped nozzles, XR 110.03, spaced $0.50 \mathrm{~m}$ apart, with consumption of $200 \mathrm{~L} \mathrm{ha}^{-1}$. At the time of application, in the morning, the wind speed, temperature and air humidity were $0.7 \mathrm{~m} \mathrm{~s}^{-1}, 29.2$ ${ }^{\circ} \mathrm{C}$ and $46.2 \%$, respectively.

For the experiment with post-emergence application of crotalaria, the herbicides were applied at 20 days after emergence (DAE) for C. juncea and C. spectabilis that developed 
faster and at 30 DAE for C. ochroleuca and C. breviflora. The same costal spray described in the previous experiment was used. At the time of application on C. juncea and C. spectabilis, the wind speed, humidity and air temperature were $2.1 \mathrm{~m} \mathrm{~s}^{-1}, 30^{\circ} \mathrm{C}$ and $56.9 \%$, and on C. ochroleuca and C. breviflora were $3.2 \mathrm{~m} \mathrm{~s}^{-1}, 27^{\circ} \mathrm{C}$ and $60.4 \%$.

For visual evaluations of toxicity, the scale of ALAM (1974) was used, in which 0 (zero) corresponds to no injury in the plant and 100 (one hundred) corresponds to plants death at 35 days after the emergence (DAE), for the treatments involving the herbicides applied in preemergence and 35 days after the application of the treatments (DAT) for the herbicides applied in the post-emergence period. At the end of the evaluations, shoot dry matter was determined. So, the plants were cut close to the neck and the harvested material was dried in a forced circulation oven $\left(60^{\circ} \mathrm{C} \pm 2^{\circ} \mathrm{C}\right)$ until reaching a constant mass. The dry matter masses of the other treatments were calculated from the control.

Data were submitted to analysis of variance $(p<0.05)$ and SigmaPlot $12.0 \AA$ software was used to adjust the regression curves.
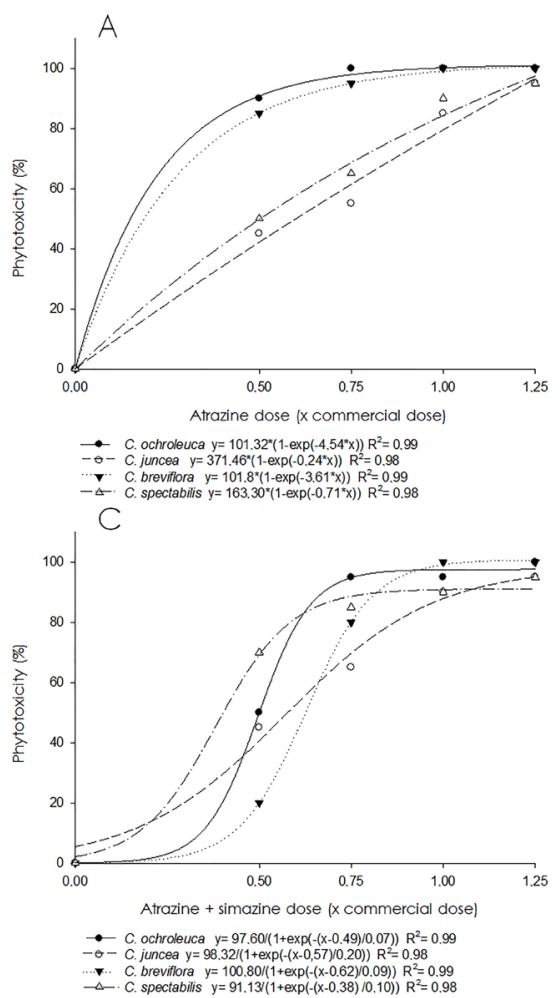

\section{Results and discussion}

Selectivity of pre-emergence herbicides

Atrazine caused toxicity in all species in the evaluated doses; however, C. ochroleuca and $C$. breviflora presented the highest percentages of phytotoxicity while C. juncea and C. spectabilis presented the lowest (Figure 1a). However, when the dry mass was observed, C. juncea had a lower impact in this variable. The dry mass of the other species was about $20 \%$ of that obtained by the control at half of the commercial dose, while at this same dose, C. juncea was $60.7 \%$. It evidences the potential use of this herbicide in sub doses and only for $C$. juncea (Figure 1b).

For the combination of atrazine + simazine it is observed a higher toxicity with the increase of doses. However, at half of the commercial dose, C. breviflora presented low phytotoxicity (20\%). Nevertheless, when the commercial dose was used, all species showed high toxicity (greater than $80 \%$ ) (Figure 1c). At half of the commercial dose, dry matter accumulation values of crotalaria species were $60 \%$ above the value obtained by the control. However, at 0.75D, only C. juncea presented potential use of the mixture.
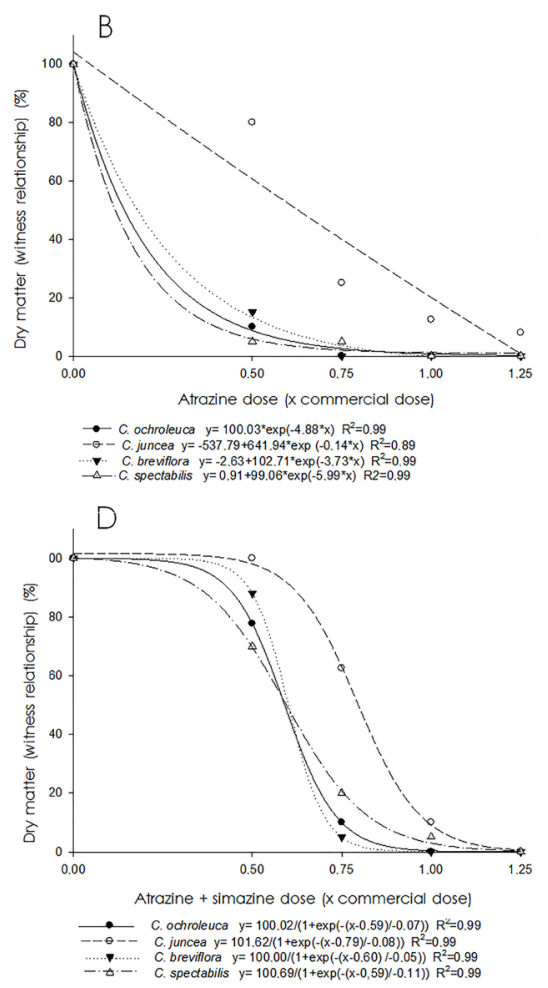

Figure 1. Phytotoxicity and mass of the shoot dry matter of Crotalaria breviflora. C. juncea, C. ochroleuca and C. spectabilis submitted to different doses of herbicides atrazine (a / b) and atrazine + simazine (c / d). 
Regarding atrazine + mesotrione, it was observed greater toxicity than or equal to $80 \%$ for all species of crotalaria and plants death at the highest dose (Figure 2a). The commercial dose of this mixture reduced the dry matter yield of the evaluated species by $100 \%$, which evidences the susceptibility of crotalaria plants to the mixture (Figure 2b). The results of phytotoxicity and accumulation of dry mass indicate potential use of the mixture in only half of the commercial dose. A number of studies have demonstrated that atrazine may be a complementary herbicide with mesotrione, since the combination of these herbicides has resulted in increased control of several weed species (Armel et al., 2005). These herbicides mixture is more effective than the isolated use of the products, with a consistent reduction of photosynthesis and dry matter of eudicots (Woodyard et al., 2009) and monocots weeds (Bolmann et al., 2006). In crotalarias, the effect of isolated atrazine and in mixture showed little difference in phytotoxicity. In some cases, a two-year interval after the application of this mixture is necessary for the cultivation of sensitive
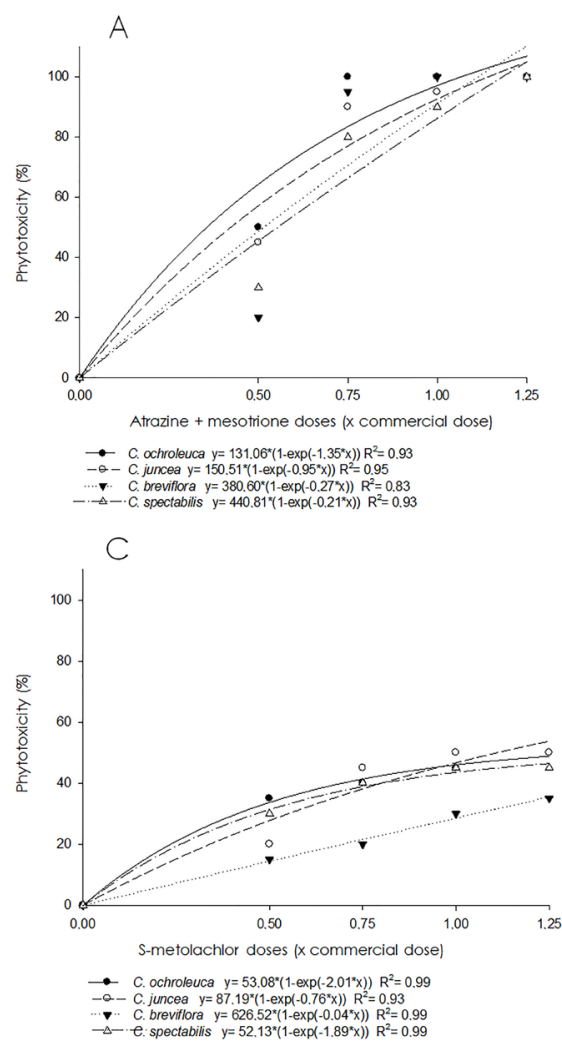

Figure 2. Phytotoxicity and mass of the shoot dry matter of Crotalaria breviflora, C. juncea, C. ochroleuca and C. spectabilis submitted to different doses of atrazine + mesotrione (a / b) and s-metolachlor (c / d). crops such as broccoli, carrot and cucumber (Robinson, 2008).

S-metolachlor showed low toxicity for all the evaluated species (Figure 2c). C. juncea and $C$. ochroleuca did not differ from the control in relation to the accumulation of dry mass. S-metolachlor also showed potential for use in C. breviflora. C. spectabilis was the most susceptible species to the herbicide, with $37 \%$ dry mass accumulation in relation to the herbicide-free control at the commercial dose (Figure 2d). In a study with selectivity of residual herbicides to common bean, the selectivity level of dimethenamid and s-metolachlor varied according to the applied dose, while the herbicides pendimethalin and trifluralin did not change. S-metolachlor did not cause damage to plants when sprayed on the registered dose. According to the authors, it can be speculated that the metabolism mechanism detoxified part of the molecules of these herbicides, whose limit was extrapolated in the highest doses (Kalsing \& Vidal, 2013).
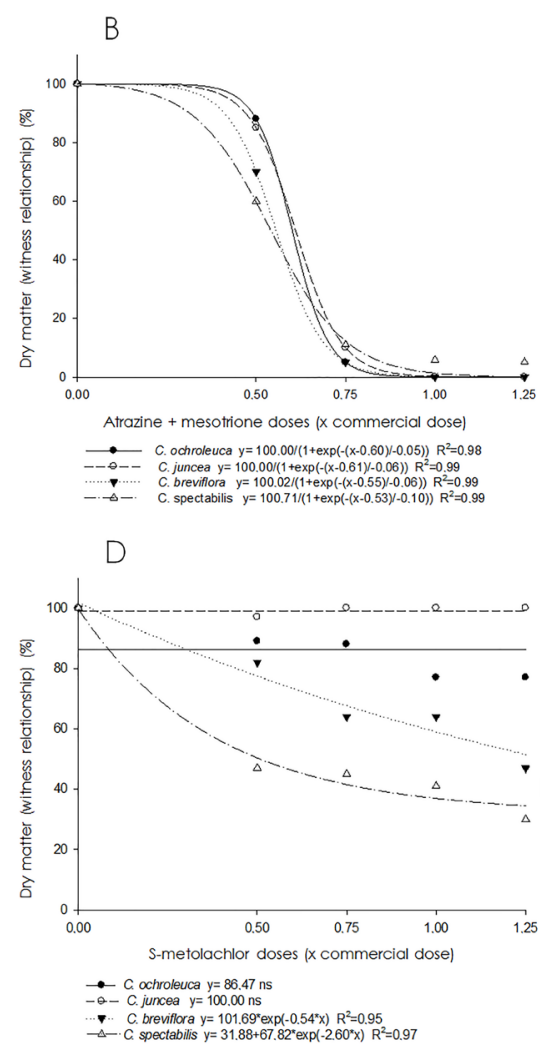
For isoxaflutole, the crotalaria species, except C. breviflora, showed high phytotoxicity at the commercial dose. Intoxication ranged from $76 \%$ (C. juncea) to $92 \%$ (C. ochroleuca) at the commercial dose, and the evolution of symptoms was verified with the use of the highest dose of the herbicide. For C. breviflora, there was $60 \%$ of intoxication at the commercial dose
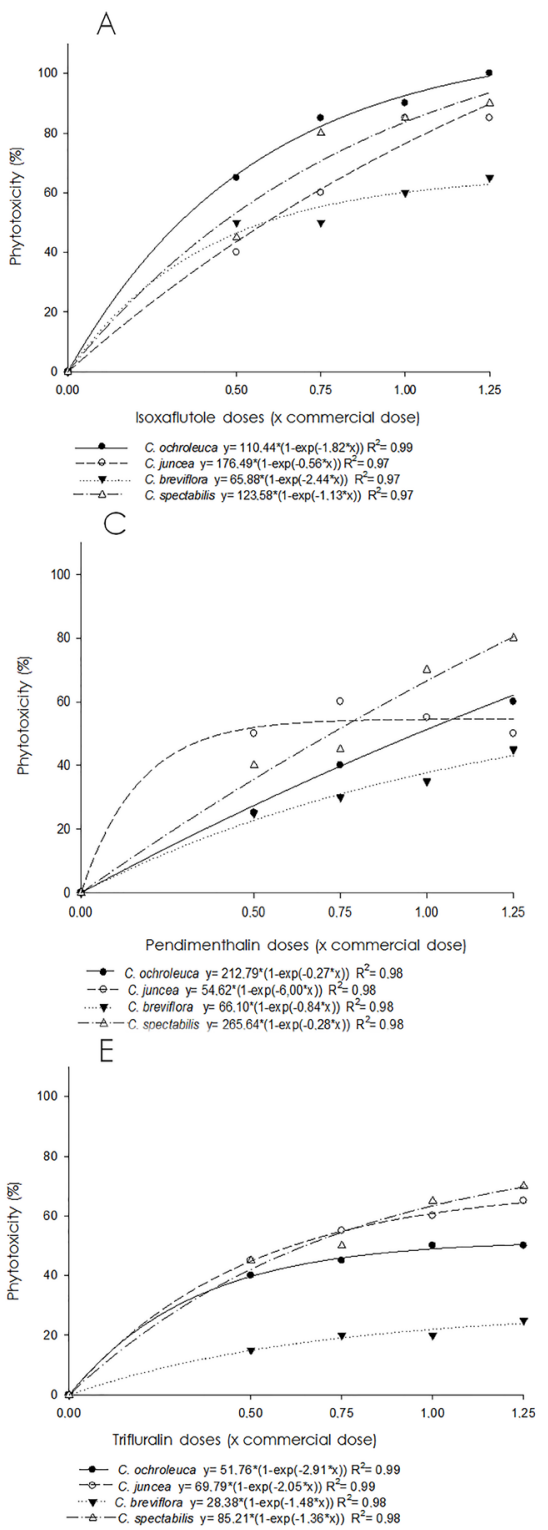

(Figure 3a). There was recovery of $C$. juncea in relation to the effects of the herbicide, and the species showed no differences in dry matter production at different doses. However, for the other crotalaria species, there was a reduction in this variable with the increase of the dose (Figure 3b).
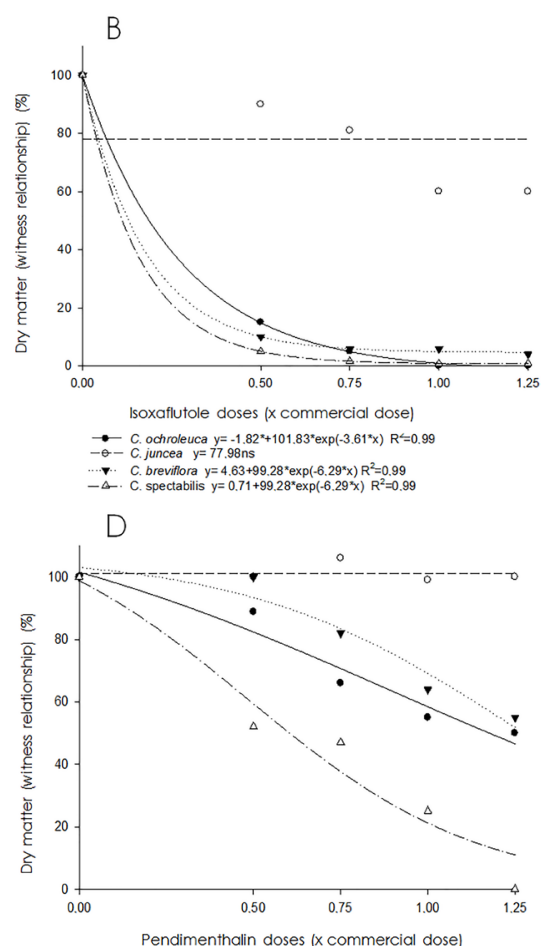

- cochros

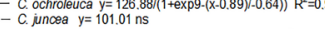

7. C. brevitforat $y=106.95 /(1+\exp (-(x-1.22)-0.37)) R^{2}=0.94$

F

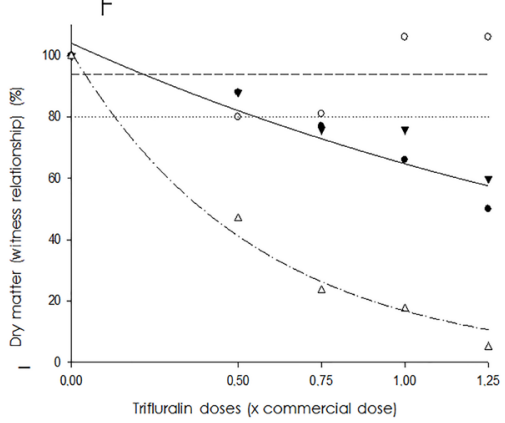

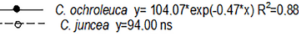

....... C. brevifora $y=7974$ no

C. spectablilis $y=101.15^{\circ} \times x p\left(-1,79^{\circ} \times\right) R^{2}=0.98$

Figure 3. Phytotoxicity and mass of the shoot dry matter of Crotalaria breviflora. C. juncea C. ochroleuca and C. spectabilis submitted to different doses of isoxaflutole (a / b) pendimenthalin ( $c / d$ ) and trifluralin (e / f).

Concerning the pedimenthalin, lower phytotoxicity symptoms were observed. C. breviflora presented phytotoxicity below $40 \%$ at the commercial dose, and this value was maintained with the use of the highest dose. The same pattern can be verified for $C$. ochroleuca and $C$. juncea. was the most susceptible species to the herbicide, with more than $60 \%$ of toxicity at the commercial dose and $80 \%$ at 1,25D (Figure $3 c)$. The results of dry mass accumulation confirm the greater susceptibility of $C$. spectabilis. The dry mass of $C$. juncea did not differ from the control without herbicide. C. ochroleuca and C. breviflora presented a dry mass accumulation of 
$70.3 \%$ and $83.5 \%$ in relation to the herbicide-free control at $0.75 \mathrm{D}$ (Figure 3d), which evidences the potential use of pendimethalin.

Trifluralin showed low phytotoxicity, with C. breviflora with $22 \%$ phytotoxicity at the commercial dose. The species C. spectabilis and $C$. juncea were more susceptible, with phytotoxicity of $63.3 \%$ and $60.8 \%$, respectively, at the commercial dose. C. ochroleuca showed an intermediate behavior, with $48.9 \%$ of toxicity at the commercial dose (Figure 3e). The dry mass of $C$. breviflora and $C$. juncea did not differ between the doses compared to the control without herbicide. C. ochroleuca was the most susceptible species to the herbicide. Concerning C. spectabilis, it can be considered as potential use with dry mass above $60 \%$ in relation to the commercial dose accumulation (Figure 3f).

Although herbicides have caused toxicity in sunflower plants, such as albino leaves (isoxaflutole), oxidative stress death is not fast. In the case of trifluralin and pedimenthalin, which inhibit tubulin polymerization, the evolution of symptoms to necrosis occurs as a consequence of the lack of roots. S-metolachlor acts by interfering with the activity of acyl-CoA elongases, which are enzymes that catalyze the synthesis of very long chain lipids, precursors of wax, suberin and cutin (Vidal et al., 2014). An explanation for the lower phytotoxicity values of pedimenthalin, s-metolachlor and trifluralin may be the result of the greater action of these products on the control of grasses.

The residual effect of pre-emergence herbicides tended to decrease with time, so herbicides with low toxicity on crotalaria species could be used in intercropping, where crotalaria would be sown after corn. The intoxication of the intercropped species can be an important tool to reduce the competitive capacity with the intercropped crop (Merotto Jr. et al., 2009).

As a result of this study, a careful association between crotalaria species, dose and adequate herbicides may allow the use of certain herbicides in the intercropping with crotalaria, which allows a more sustainable production system.
Selectivity of post-emergence herbicides

In the trials involving post-emergence herbicides, C. spectabilis showed high susceptibility to 2,4-D herbicide. The plants presented chlorosis and leaf epithelia even at the lowest doses. C. juncea, C. ochroleuca and C. breviflora presented similar behavior with $0.75 \mathrm{D}$ (phytotoxicity around 40\%). At the commercial dose, there was high toxicity (greater than or equal to $80 \%$ ) in C. ochroleuca and C spectabilis (Figure 4a), which resulted in a lower accumulation of dry mass (Figure 4b). In contrast, C. juncea and C. breviflora had slightly lower toxicity values (67\% and $54.9 \%$, respectively) at the commercial dose, which resulted in a higher accumulation of dry matter in relation to the other species. C. breviflora did not differ from the control without herbicide with the increase of the doses, which shows potential use for this herbicide, being necessary only an adjustment of doses aiming at the reduction of injuries. Oliveira Neto et al. (2011) found that different doses of 2,4-D (2010, 2680 and $3350 \mathrm{~g} \mathrm{ha}^{-1}$ ) also caused differentiated toxicity $(40.8 \%, 48.8 \%$ and $71.5 \%$, respectively) when applied in plants of $C$. spectabilis adults in the vegetative phase.

For ametryn, C. juncea, C. breviflora and C. ochroleuca presented similar behavior, with phytotoxicity greater than $80 \%$, at the commercial dose. C. spectabilis presented higher susceptibility to this herbicide, with phytotoxicity at $0.5 \mathrm{D}$ and $0.75 \mathrm{D}$, with about $80 \%$ and $100 \%$, respectively (Figure 4c). This herbicide, mainly from the commercial dose, negatively affected the dry matter production of all species of crotalaria, mainly the C. spectabilis. C. ochroleuca and C. breviflora presented a dry mass superior to the other crotalaria in the lowest dose of the herbicide (0.5D), which shows less susceptibility of these species (Figure 4d).

The different susceptibility of the species allows the adjustment of the herbicides dose. These data corroborate with those found by Briguenti et al. (2011) who verified differentiated susceptibility among brachiaria species (U. brizantha, $U$. decumbens and $U$. ruziziensis) for the same active principle.

At the commercial dose, amicarbazone showed effective control of all crotalaria species 

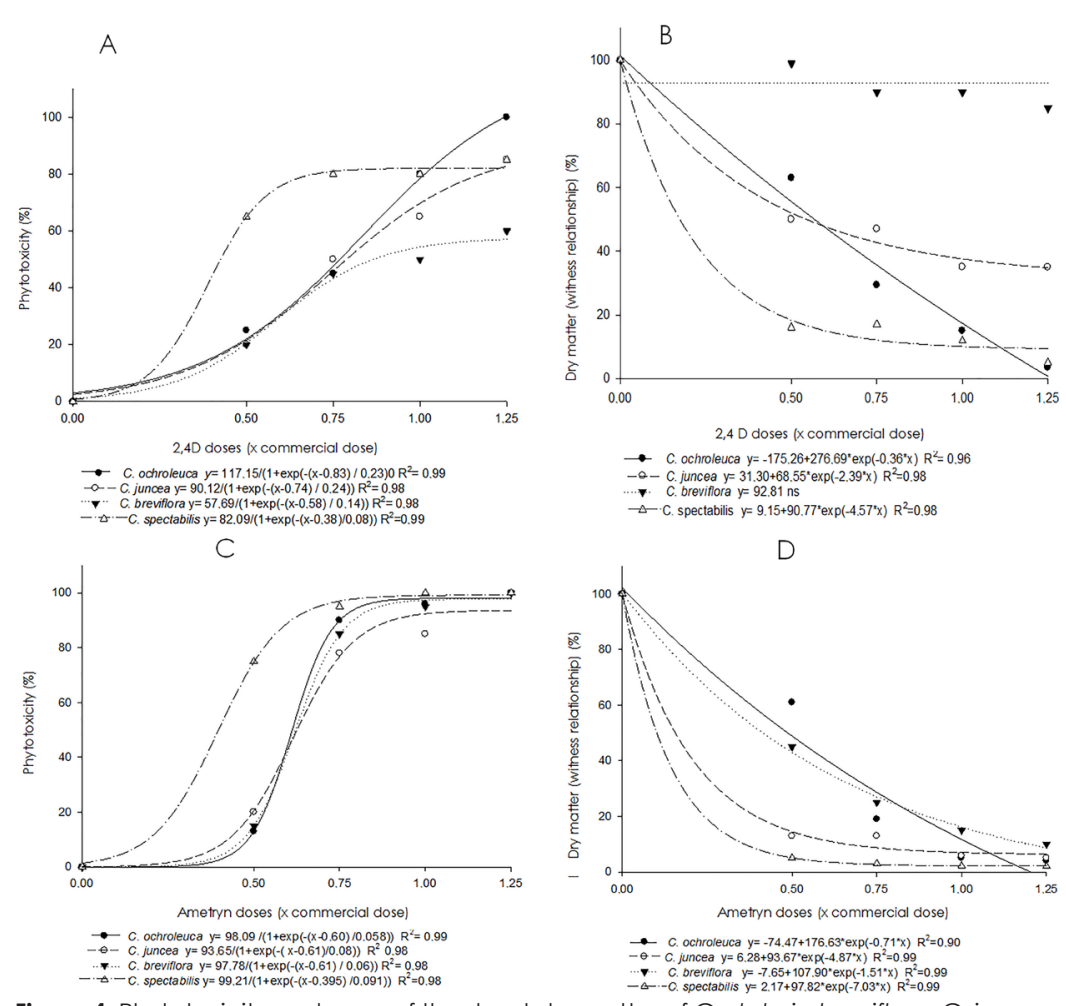

Figure 4. Phytotoxicity and mass of the shoot dry matter of Crotalaria breviflora. C. juncea, C. ochroleuca and C. spectabilis submitted to different doses of 2,4D (a / b) and ametryn (c/d).

(Figure 5a). Even at lower doses, C. breviflora presented dry mass, with $56.7 \%$ and $36.8 \%$ of the control values at doses of 0.50 and $0.75 \mathrm{D}$, respectively (Figure $5 b$ ).

Among the herbicides applied in postemergence, bentazon can be distinguished with the lowest levels of intoxication on crotalaria species. The greatest symptoms of phytotoxicity were observed in C. spectabilis, where the highest dose promoted $35.3 \%$ of phytotoxicity. For the other species, the symptoms were less pronounced, with values close to $20 \%$ at the highest dose (Figure 5c). C. ochroleuca and C. breviflora showed a dry mass accumulation similar to that of the control, regardless of the dose, which evidences selectivity of this herbicide for these species. For $C$. juncea, dry matter production decreased as the herbicide dose increased, which also occurred for $C$. spectabilis (Figure $5 d$ ). C. juncea was less susceptible to the herbicide than C. spectabilis with dry matter accumulation at the commercial dose (1 D) of $74 \%$ and $43 \%$ of the control accumulation without herbicide application, respectively, for $C$. juncea and $C$. spectabilis, which shows use potential even for these species, in smaller doses. Bentazon has as a mechanism of action to inhibit photosystem II (PSII), and the selectivity to this herbicide can be related to the rapid metabolism of the molecule to non-toxic forms, which prevents plant death (Roman, 2007).

The phytotoxicity provided by mesotrione was distinct among the crotalaria species. However, in general, there was low selectivity. C. ochroleuca presented greater susceptibility to the herbicide. There was a negative impact on the accumulation of dry mass of the species treated with herbicide (Figure 6a). At half of the commercial dose, the best dry mass accumulation results were obtained by $C$. juncea $(37.4 \%$ of the dry mass verified in the control without herbicide) (Figure 6b).

Crotalaria species differ in relation to the morphology and biomass allocation, which may explain the difference in susceptibility in relation to the herbicides. Amabile et al. (2000) verified a dry mass yield of $17.2 \dagger$ ha $^{-1}$ for $C$. juncea and $8.8 \dagger$ $\mathrm{ha}^{-1}$ for $\mathrm{C}$. ochroleuca, which shows the difference in size between these species. When the leaves of plants present different morphoanatomic characteristics, these differences may imply effects in the interception of the herbicide and 
consequently changes in its effectiveness (Inacio \& Monquero, 2011).

In an experiment involving the intercropping of corn with different species of crotalaria, C. juncea accumulated more dry matter than C. spectabilis (Gitti et al., 2012). C. juncea presents rapid growth up to 40 days

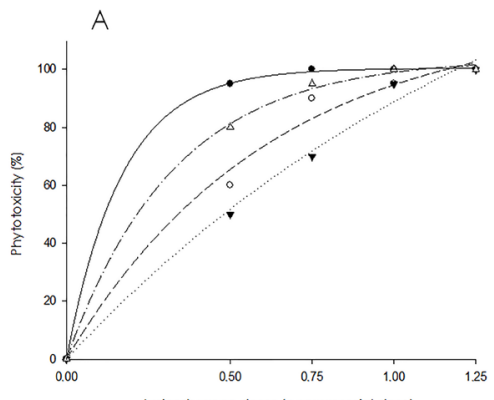

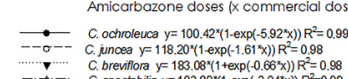
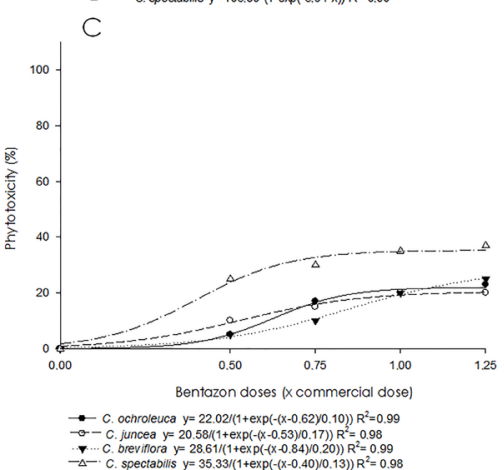

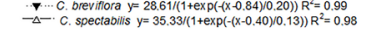

Figure 5. Phytotoxicity and mass of the shoot dry matter of Crotalaria breviflora. C. juncea, C. ochroleuca and C. spectabilis submitted to different doses of amicarbazone (a / b) and bentazon (c/d).
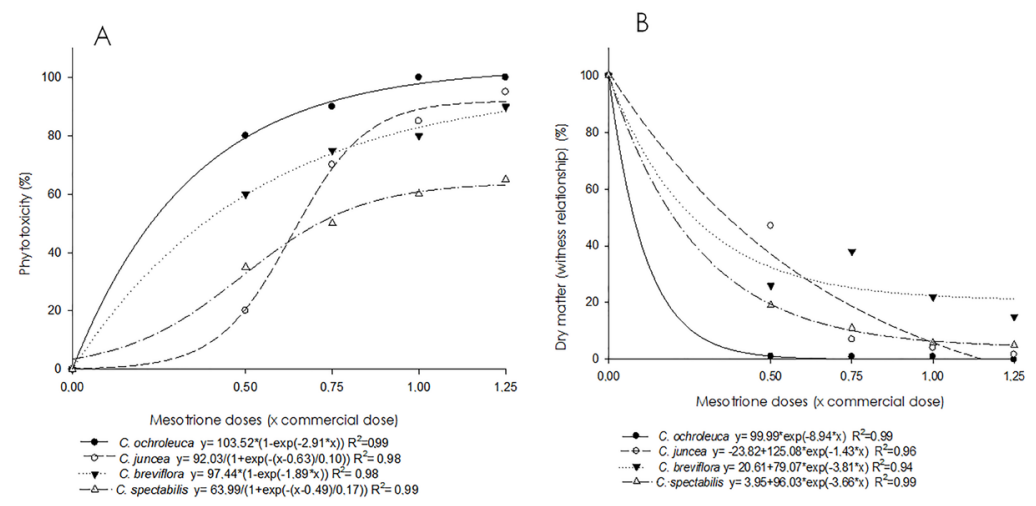

Figure 6. Phytotoxicity (a) and mass of the shoot dry matter (b) of Crotalaria breviflora. C. juncea, C. ochroleuca and C. spectabilis submitted to different doses of mesotrione.

\section{Conclusion}

There is a difference in susceptibility among crotalaria species in relation to pre and post-emergence herbicides. Among the herbicides applied in post-emergence, bentazon was the most selective. For herbicides used in pre-emergence, the most selective were after sowing (DAS), being reduced in the period between 40 and 60 DAS and, after 60 DAS, resumes the accelerated growth, different from C. spectabilis, which has a slow and constant growth rate (Oliveira \& Gosch, 2007; Teodoro et al., 2011).

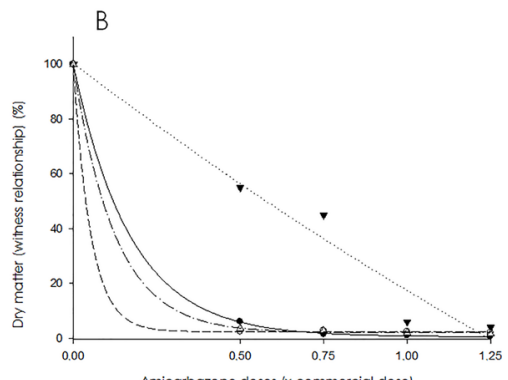

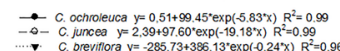

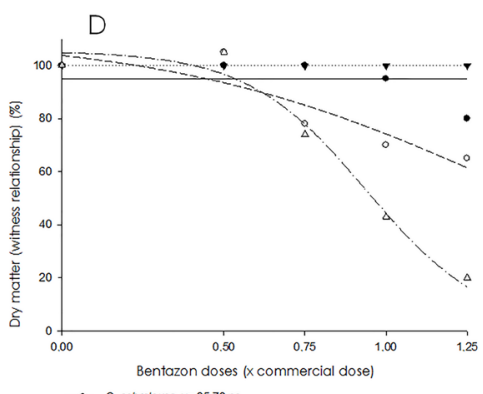

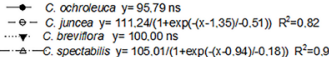

\section{(n)}


Latinoamérica. Revista de la Asociación Latinoamericana de Malezas 1: 6-38.

Araujo, F.F., Bragante, R.J., Bragante, C.E. 2012. Controle genético, químico e biológico de Meloidoginose na cultura da soja. Pesquisa Agropecuaria Tropical 42: 220-224.

Amabile, R.F.; Fancelli, A.L.; Carvalho, A.M. 2000. Comportamento de espécies de adubos verdes em diferentes épocas de semeadura e espaçamentos na região dos cerrados. Pesquisa Agropecuária Brasileira 35: 47-54.

Asmus, G.L.; Richetti, A. 2010. Rotação de culturas para o manejo do nematoide reniforme em algodoeiro. Dourados: Embrapa Agropecuária Oeste. Brasil. 26p.

Armel, G.R., Hall, G.J., Wilson, H.P., Cullen, N. 2005. Mesotrione plus atrazine mixtures for control of Canada thistle (Cirsium arvense). Weed Science 53: 202-211.

Bollman, S.L., Kells, J.J., Penner, D. 2006. Weed response to mesotrione and atrazine applied alone and in combination preemergence. Weed Technology, 20: 903-907.

Brighenti, A.M., Sobrinho, F.S., Rocha, W.S.D., Martins, C.E., Demartini, D., Rodrigues, T.C. 2011. Suscetibilidade diferencial de espécies de braquiária ao herbicida glifosato. Pesquisa agropecuária brasileira. $46: 1241-1246$.

Carneiro, R.G., Moritz, M.P., Mônaco, A.P.A., Nakamura, K.C, Scherer, A. 2007. Reação de milho, sorgo de milheto a Meloidogyne incognita, M. javanica e a M. paranaensis. Nematologia Brasileira 31: 67-71.

EMPRESA BRASILEIRA DE PESQUISA AGROPECUÁRIA - EMBRAPA. 1999. Sistema brasileiro de classificação de solos. Rio de Janeiro, Ministério da Agricultura e do Abastecimento, 412p.

Espanhol, M., Parreira, M.C., Duarte, D.J.; Correia, N.M. 2011 . Dessecação de Crotalaria juncea no outono. Revista Brasileira de Ciências Agrárias 6: 90-97.

Gardiano, C.C., Giareta, R.D., Lopes, E.A., Zooca, R.J.F., Ferraz, S., Freitas, L. G. 2010. Atividade nematicida de extratos de sementes de espécies de crotalaria sobre Meloidogyne javanica. Revista Trópica - Ciências Agrárias e Biológicas 4: 3-6.

Gitti, D.C. 2012. Épocas de semeadura de crotalária em consórcio com milho. Revista Brasileira de Milho e Sorgo 11: 156-168.

Kappes, C., Valentini, M., Orivaldo, A., Gitti, D.C. 2012. Resposta da crotalária à épocas e subdoses de aplicação de glyphosate. Bioscience Journal 28: 373-383.

Kalsing, A.; Vidal, R.A. 2013. Seletividade de herbicidas residuais ao feijão-comum durante - período inicial da fase vegetativa. Planta daninha 31: 411-417.

Inove, M.H., Duarte, J.C.B., Mendes, K.F., Sztoltz, J., Ben, R., Pereira, R.L. 2012. Eficácia de herbicidas aplicados em plantas adultas de Crotalaria spectabilis e Crotalaria ochroleuca. Revista Brasileira de Herbicidas 11:148-58.

Merotto Jr.A., Fischer, A.J., Vidal, R. A. 2009. Perspectives for using light quality knowledge as an advanced ecophysiological weed management tool. Planta Daninha 27: 407-419.

Inacio, S.M., Monquero, P.A. 2013. Controle químico e caracterização da superfície foliar de Conyza bonariensis e C. canadensis (Asteraceae). Revista Brasileira de Herbicidas 12:220-231.

Oliveira, F.L.; Gosch, M.S. 2007. Potencial de leguminosas herbáceas de hábito ereto para adubação verde no cerrado do Tocantins. Revista de Ciências Agroambientais 2:17-24.

Oliveira Neto, A.M. Goes Maciel, C.D., Guerra, N., Ramos Lima, G.G., Sola Júnior, J,L. 2011 . Manejo químico de adubos verdes para sucessão da cana-de-açúcar em sistema de cultivo mínimo. Revista Brasileira de Herbicidas 10:86-94.

Pires, F. R., Procopio, S.O., Dos Santos, J.B., Souza, C.M.; Dias, R.R. 2008. Avaliação da fitorremediação de tebuthiuron utilizando Crotalaria juncea como planta indicadora. Revista Ciência Agronômica 39: 245-250.

Robinson, D.E. 2008. Atrazine Accentuates Carryover Injury from Mesotrione in Vegetable Crops. Weed Technology 22:641-645.

Roman, E. S. 2007. Como funcionam os herbicidas: da biologia à aplicação. Passo Fundo: Berthier, 160 p.

Ritzinger, C.H.S.P, Fancelli, M. 2006. Manejo integrado de nematóides na cultura da bananeira. Revista Brasileira de Fruticultura 28: 331-338.

Teodoro, R.B. Oliveira, F.L., Silva, D.M.N., Fávero, C., Quaresma, M.A.L. 2011. Aspectos agronômicos de leguminosas para adubação verde no Cerrado do alto vale do Jequitinhonha. Revista Brasileira de Ciência do Solo 35: 635-643.

Torres, J.L.R.; Pereira, M.G.; Fabian, A.J. 2008. Produção de fitomassa por plantas de cobertura e mineralização de seus resíduos em plantio direto. Pesquisa Agropecuária Brasileira 43:421-428. 
Vidal, R.A. 2014. Mecanismos de ação dos herbicidas. In: Monquero, P.A. (org.). Aspectos da biologia e manejo das plantas daninhas. São Carlos: Rima,. p. 235-255.

Woodyard, A,. Hugie, J.A., Riechers, D.E. 2009. Interactions of mesotrione and atrazine in two weed species with different mechanisms for atrazine resistance. Weed Science 57(4):369-378. 